\title{
Implementasi Diagnosis Organisasi pada Perguruan Tinggi Swasta (PTS) di Kota Jambi
}

\author{
Jonner Simarmata, Said Almaududi \\ Fakultas Ekonomi Universitas Batanghari Jambi, Indonesia \\ Correspondence email: jonnerunbari@gmail.com \\ Email: saidalmaududi@yahoo.com
}

\begin{abstract}
Organizational effectiveness positively impacts sustainability and competitiveness of organizations. Higher Education is no exception. To gain sustainability and effectiveness of organizations, diagnosis should be implemented regularly. In theory, organizations that implement diagnosis regularly have sustainable competitiveness. Today, Higher Educations face tough competition due to many factors suchs as globalization, technological advancement, and rapid demographic changes. This current research aims at implementing organizational diagnosis on Private Higher Educations (PHEs) in Jambi City. Specifically, the purpose of this diagnosis is to know how effective is the organizations in terms of purpose, structure, leadership, relationship, rewards, mechanism, attitutde toward changes, and learning practices. For this purpose, a set of questionaires were distributed to respondents who were cluster-randomly selected from four institutions. Data analysis shows that in general higher education organization in Jambi City is considered sufficiently effective. This suggests that improvement should be made. In particular, there are three organizational aspects that respondents give the lowest score. They are reward system, attitude toward changes, and learning practices. This means that these three variabels should be given more attention by top managers.
\end{abstract}

Keywords: Organizational Diagnosis, Organizational Effectiveness, Private Higher Educations

\section{PENDAHULUAN}

Perguruan Tinggi (PT) adalah organisasi. Dengan demikian, PT memiliki komponen-komponen layaknya organisasi lain. Tujuan utama PT adalah menghasilkan lulusan yang berkualitas. Menurut konsep Tridarma Perguruan Tinggi terdapat tiga tugas utama PT, yakni: melakukan pengajaran, penelitian dan pengabdian kepada masyarakat (Simarmata, 2018). Untuk menghasilkan kinerja yang baik, semua komponen yang ada harus mampu berkolaborasi dengan baik. Dengan kata lain, setiap komponen harus mampu melakukan fungsinya masing-masing. Cooper (2015) mengemukakan bahwa PT dewasa ini mengalami perubahan yang mendasar. Terdapat paling tidak dua alasan perubahan tersebut. Pertama, meningkatnya tekanan lingkungan eksternal seperti berkurangnya sumber-sumber keuangan, meningkatnya tuntutan masyarakat akan mutu, terjadinya perubahan demografik, dan kemajuan teknologi. Kedua, perguruan tinggi yang sebelumnya dianggap sebagai lembaga pelayanan publik berubah menjadi sektor ekonomi. Akibatnya, para pemimpin di PT dalam menjalankan operasinya menerapkan praktek-praktek bisnis seperti menjaga asset dan liabilitas, menyeimbangkan biaya dan untung, meningkatkan efisiensi dan efektivitas, dan menjaga dan meningkatkan kepuasan pelanggan. Intinya, dewasa ini PT telah berubah menjadi bisnis

Perubahan-perubahan tersebut memicu terjadinya persaingan yang sangat ketat. Setiap organisasi ingin menjadi pemenang. Ingin menjadi nomor satu. Akibatnya, organisasi-organisasi, terutama organisasi bisnis berusaha melakukan perubahan internal agar mampu memenangkan persaingan tersebut. Organisasi yang mampu memenangkan persaingan adalah organisasi yang sehat. Organisasi yang sehat akan dapat beroperasi secara efisien dan efektif. Sebaliknya, organisasi yang tidak sehat diyakini tidak dapat mengelola organisasinya dengan baik. Sehingga tidak dapat bersaing dengan baik. Saeed \& Wang (2013a) mengemukakan globalisasi, perubahan demografik, kemajuan teknologi adalah beberapa faktor eksternal yang dapat mempengaruhi kinerja organisasi. Oleh sebab itu, agar mampu memenuhi kebutuhan para stakeholder, para pemimpin perusahaan harus mampu secara cepat mengidentifikasi kekurangan-kekurangan yang dimiliki perusahaannya dan segera memperbaikinya dengan tepat. Agar mampu melakukan ini maka perlu dilakukan diagnosis organisasional atau organizational diagnosis (OD).

Melakukan diagnosis bukanlah hal yang mudah. Diperlukan alat yang tepat agar dapat memberi hasil diagnosis yang tepat. Diagnosis yang salah tentu saja akan menghasilkan analisis yang salah pula. Dengan demikian, solusi yang diberikan pun akan tidak tepat. Pada konteks perguruan tinggi khususnya PTS di Kota Jambi, kajian tentang efektivitas organisasi belum banyak dilakukan. Penelitian ini bertujuan untuk 
menjembatani gap ini dengan melakukan diagnosis organisasional. Secara khusus, penelitian ini bertujuan untuk mengkaji apakah learning practices merupakan aspek yang signifikan dalam model diagnosis organisasional.

\section{Landasan Teori \\ Diagnosis Organisasi}

Miles (2012:7) mendefinisikan organisasi sebagai kerjasama orang-orang yang berkumpul secara sukarela dan terstruktur untuk mencapai tujuan bersama. Dengan kata lain, organisasi bukan kumpulan orang-orang yang bertemu secara kebetulan akan tetapi organisasi dibentuk secara sengaja menjadi sebuah entitas untuk mencapai tujuan yang tidak dapat dicapai secara individual saja. Lebih lanjut dikatakan bahwa organisasi adalah sebuah managed system atau sistem terkelola yang didesain dan dioperasikan untuk mencapai misi, visi, strategi, dan tujuan. Menurut Burke \& Litwin (1992), organisasi terdiri dari beberapa sub-kelompok atau sub-sistem yang memiliki kesalingtergantungan. Dengan demikian, setiap elemen tidak dapat dipandang secara terpisah dari elemen lain. Ini berarti, dalam menjalankan perannya, setiap elemen membutuhkan elemen lain.

Alderfer (2011:73-94) mencatat bahwa kajian tentang diagnosis organisasi telah dimulai sejak Perang Dunia (PD) II. Pada awalnya, fokus dari kajian ini adalah model dan metode. Orang-orang yang mula-mula melakukan kajian ini adalah Levinson, Argyris, dan Schein. Mereka adalah para sarjana yang juga praktisi (scholar practitioner). Levinson melakukan kajian di bidang psikoanalisis; Argyris di bidang sosiologi; dan Schein di bidang hubungan sosial secara multidisiplin. Hamid et al (2011) mendefinisikan diagnosis sebagai cara untuk memeriksa organisasi untuk menentukan gap atau variansi antara apa yang terjadi dengan apa yang diharapkan. Sedangkan Harrison \& Shirom, (1999:7) mengatakan bahwa diagnosis adalah penyelidikan dengan menggunakan konsep, model, dan metode yang didasarkan pada ilmu perilaku terhadap keadaan organisasi terkini dalam rangka menyelesaikan masalah dan meningkatkan keefektifan organisasi. Sebuah organisasi dikategorikan efektif apabila organisasi tersebut dapat mencapai tujuan dengan baik (Burke \& Litwin, 1992).

Untuk meningkatkan daya saing, pemimpin perusahaan dianjurkan untuk mampu secara cepat untuk mengidentifikasi kelemahan-kelamahan organisasinya dan bertindak sesuai dengan hasil identifikasi tersebut (Whitfield \& Landeros, 2006; Saeed \& Wang, 2013b). Salah satu cara untuk melakukan identifikasi kelemahan tersebut adalah dengan melakukan diagnosis organisasi. Model Diagniosis Organisasional adalah representasi, biasanya secara metaforik, dari sebuah organisasi (Howard, 1994). Ia adalah kerangka konseptual yang digunakan untuk memahami organisasi (Cummings \& Worley, 2008). Cummings dan Worley menguraikan hubungan fitur-fitur organisasi yang berbeda-beda, juga menjelaskan konteks dan keefektifan organisasi, yang demikian, mengungkapkan bagian-bagian mana dari organisasi yang perlu diperiksa dan pertanyaan apa yang perlu diajukan untuk menilai apakah fungsi-fungsi organisasi berjalan dengan baik. Menurut Harrison dan Shirom (1998), model diagnostik sangat mampu memberi feedback kepada klien, membentuk pilihan yang akan diambil untuk melakukan intervensi perubahan, dan menentukan langkah-langkah efektif dalam kegiatan konsultasi organisasi.

Hingga saat ini telah terdapat sejumlah model diagnosis organisasi. Salah satunya adalah model enam kotak (Six Box Model) yang dikembangkan oleh Weisbord (1976). Weisbord mengembangkan model ini untuk mendiagnosis keefektifan organisasi. Weisbord mengidentifikasi enam bidang yang penting dalam organisasi. Enam bidang ini harus sehat dan konsisten secara internal untuk menuju keberhasilan. Hasil dari diagnosis tersebut adalah terdapat sejumlah tindakan yang direkomendasikan untuk memperbaiki efektivitas organisasi atau yang dapat mendorong organisasi melakukan perubahan. Karena aspek yang didiagnosis tersebut terdiri dari enam macam maka sejak itu instrument ini disebut dengan Model Enam Kotak. Para pakar menilai, Model Enam Kotak merupakan alat diagnosis organisasi yang paling sederhana dan mudah digunakan (Harrison dan Shirom, 1999:7). Keenam aspek besar yang dijadikan sebagai dasar penilaian terhadap kesehatan organisasi tersebut adalah: 1) tujuan, 2) struktur, 3) hubungan, 4) kepemimpinan, 5) imbalan, 6) mekanisme (Weisbord, 1976). Namun, belakangan Model Enam Kotak ini dikembangkan lagi sehingga aspek yang didiagnosis tidak hanya enam aspek akan tetapi ditambah beberapa aspek lagi sesuai kebutuhan. Misalnya, Preziosi (1980) menambahkan satu variabel yakni sikap terhadap perubahan. Hebatnya, model ini dapat beradaptasi dengan perubahan yang dibuat oleh para pakar peneliti. 


\section{Perguruan Tinggi}

Pemerintah saat ini berkomitmen untuk meningkatkan kualitas perguruan tinggi (PT). Telah banyak kebijakan yang diambil untuk itu. Dua di antaranya adalah melakukan akreditasi dan klasterisasi. Peningkatan kualitas PT ini sejalan pula dengan kebijakan pemerintah untuk meningkatkan daya saing bangsa dan kebijakan yang menjadikan PT sebagai sektor ekonomi. Dengan lingkungan global dewasa ini, PT yang berkualitas menjadi sebuah keniscayaan. Sistem pendidikan tinggi yang baik dapat menyokong dan meningkatkan kemajuan ekonomi suatu bangsa. Namun, banyak negara berkembang atau negara dalam transisi menghadapi persaingan global yang sangat ketat. Hal ini disebabkan, sistem pendidikan tinggi yang dimiliki tidak memiliki kemampuan yang memadai untuk menciptakan dan menggunakan pengetahuan (knowledge) dalam menghadapi perubahan-perubahan yang cepat. Mengubah tantangan menjadi peluang sangat tegantung kepada kemampuan beradaptasi sebuah organisasi termasuk perguruan tinggi. Peran utama PT adalah untuk melakukan transformasi kepada mahasiswa dengan cara: 1) meningkatkan pengetahuan, keterampilan, sikap, dan kemampuan; 2) menjadikan mahsiswa kritis dan reflektif (Harvey, 2000). Berdasarkan konsep tridarma perguruan tinggi, tugas PT adalah menyelanggarakan pendidikan, penelitian, dan pengabdian kepada masyarakat.

\section{Penelitian Terdahulu}

Berdasarkan hasil penelitian Hamid, et al (2011), Model Six Box dari Weisbord dapat digunakan untuk melakukan analisis kesehatan organisasional pada perguruan tinggi. Fokus dari penelitian ini adalah untuk mengetahui aspek-aspek apakah dari organisasi yang diteliti mengalami kelemahan dan perlu diperbaiki. Ditemukan bahwa, pada beberapa universitas yang diteliti, yang perlu diperbaiki adalah kejelasan tujuan, struktur, dan mekanisme kerja. Lok dan Crawford (2000) mengintegrasikan ODQ dari Preziosi yang dikembangkan pada tahun 1980 dan OEQ dari Steel yang dikembangkan pada tahun 1987. Menurut mereka kedua alat ini dapat digunakan secara bersamaan untuk menilai kesehatan organisasi. Penelitian mereka juga membuktikan bahwa ODQ dari Preziosi konsisten dengan Model Weisbord (1976).

Stegrean et al (2010) juga menggunakan Model Six Box untuk melakukan diagnosis organisai terhadap perguruan tinggi. Namun mereka menambahkan dua variable lain yakni external environment dan organizational performance sehingga kesemuanya terdapat delapan variable. Berdasarkan temuan penelitian ini, kedelapan variable tersebut memiliki dampak positif dan signifikan terhadap kinerja organisasi. Mamilo (2016) membandingkan kinerja dua organisasi pelayanan publik di dua negara yang berbeda yakni Albania dan Kosovo dengan menggunakan ODQ yang didasarkan kepada Model Weisbord. Ditemukan bahwa organisasi pelayanan publik di Albania lebih efektif dibandingakan dengan pelayanan publik di Kosovo. Ini membuktikan bahwa ODQ juga dapat digunakan untuk menilai keefektifan organisasi pada dua negara yang berbeda.

\section{METODE}

Populasi dari penelitian ini adalah semua dosen PTS yang ada di Kota Jambi sedangkan untuk penarikan sampel digunakan teknik cluster-random sampling. Pertama, PTS yang ada dikelompokkan ke dalam empat kelompok sesuai dengan jenisnya yakni (1) kelompok universitas, (2) kelompok sekolah tinggi, (3) kelompok akademi, dan (4) kelompok politeknik. Kemudian, dari masing-masing kelompok dipilih satu PTS dengan kriteria pemilihan jumlah dosen terbanyak. Terakhir, dari masing-masing PTS terpilih ditarik sampel sebesar 25\% dengan penarikan secara random. Berdasarkan prosedur ini terdapat 87 orang yang menjadi sampel penelitian ini. Dalam penelitian ini terdapat delapan variabel yakni (1) tujuan, (2) struktur, (3) kepemiipinan, (4) hubungan, (5) imbalan, (6) mekanise, (7) sikap terhadap perubahan, dan (8) learning practices. Masing-masing variabel diukur oleh lima indikator. Seperangkat angket digunakan untuk menjaring data yang dibutuhkan. Angket ini dikembangkan dari Model Preziosi. Berdasarkan Model Preziosi terdapat tujuh variabel yang diukur dengan lima indikator untuk masing-masing sehingga terdapat 35 item. Dalam penelitian ini ditambahkan satu lagi variabel yakni learning practices dengan lima indikator yang dikembangkan sendiri oleh peneliti. Sehingga secara keseluruhan terdapat 40 item pernyataan. Angket disebarkan secara langsung kepada responden dengan tenggat waktu pengembalian kurang lebih dua minggu. Angket menggunakan Skala Likert 7-poin, dengan rincian $7=$ sangat setuju, $6=$ agak setuju, $5=$ 
setuju, 4 = ragu-ragu, 3 = kurang setuju, 2 = tidak setuju, dan 1 = sangat tidak setuju. Responden diminta memilih salah satu pilihan sesuai dengan kondisi mereka saat mengisi angket.

\section{Validitas dan Reliabilitas Instrumen}

Instrumen yang baik harus memenuhi kriteria validitas dan reliabilitas. Validitas maksudnya adalah bahwa instrumen yang digunakan dapat mengukur apa yang hendak diukur sedangkan reliabilitas maksudnya adalah bahwa instrumen tersebut konsisten dalam pengukurannya (Sugiyono, 2013). Untuk mengukur validitas instrumen dalam penelitian ini digunakan teknik Korelasi dari Pearson's Product Moment dengan membandingkan nilai r-hitung dengan $r$-tabel. Instrumen dinyatakan valid jika nilai $r$ hitung lebih besar daripada nilai r-tabel pada taraf signifikansi 0,05. Sedangkan untuk uji reliabilitas digunakan Cronbach's Alpha Coefficient dengan kriteria pengujian: instrument dinyatakan reliabel jika nilai coeffisien alpha lebih dari 0,5. Hasil uji validitas dan reliabilitas dengan menggunakan SPSS Versi 24 dapat dilihat pada tabel berikut:

Tabel 1

Hasil Uji Validitas dan Reliabilitas Instrumen

\begin{tabular}{llrrr}
\hline No & \multicolumn{1}{c}{ Variabel } & $\begin{array}{c}\text { Pearson's Correlation } \\
\text { Coeffcient }\end{array}$ & $\begin{array}{c}\text { Cronbach Alpha } \\
\text { Coeffcient }\end{array}$ & P-Value (Sig.) \\
\hline 1 & Tujuan & 0,743 & 0,741 & 0,000 \\
2 & Struktur & 0,945 & 0,912 & 0,000 \\
3 & Kepemimpinan & 0,881 & 0,926 & 0,000 \\
4 & Hubungan & 0,704 & 0,733 & 0,000 \\
5 & Imbalan & 0,866 & 0,875 & 0,000 \\
6 & Mekanisme & 0,626 & 0,855 & 0,000 \\
7 & Sikap terhadap perubahan & 0,626 & 0,608 & 0,000 \\
8 & Learning practices & 0,893 & 0,869 & 0,000 \\
\hline
\end{tabular}

Sumber: data olahan

Daftar Tabel Pearson's Product Moment diketahui bahwa nilai r-tabel $=0,210$ pada $\mathrm{df}=85$, dan $\alpha=$ 0,05. Dari tabel 1 diketahui bahwa koefisien korelasi semua variabel berada di atas nilai $r$-tabel sehingga semua variabel dinyatakan valid. Demikian pula koefisien Cronbach Alpha, dari tabel 1, terlihat semuanya di atas 0,5 sehingga instrumen dinilai reliabel.

\section{Analisis Data}

Analsis data yang digunakan dalam penelitian ini utamanya adalah statistik sederhana yakni tabulasi data. Untuk melakukan tabulasi data ini terlebih dahulu ditetapkan skor ideal, skor aktual, kemudian dicari nilai skor. Skor ideal adalah skor maksimum dari Skala Likert 7-poin dikalikan dengan jumlah responden yakni 7 x $87=609$. Skor aktual adalah penjumlahan skor yang diberikan responden kepada setiap item pertanyaan yang ada dalam angket. Sedangkan nilai skor dicari dengan rumus berikut:

$$
\text { Nilai Skor }=\frac{\text { Skor Aktual }}{\text { Skor ideal }} \times 100 \%
$$

Pengkategorian nilai skor yakni sangat tinggi, tinggi, cukup tinggi, rendah, dan sangat rendah didasarkan kepada metode Weight Mean Score (Sugiyono, 2013). Skor atau nilai 80-100 dikategorikan sangat tinggi, 60-79,99 dikategorikan tinggi, 40-59,99 dikategorikan cukup tinggi, 20-39,99 dikategorikan rendah, dan 0-19,99 dikategorikan sangat rendah.

\section{HASIL}

Seluruh responden penelitian ini berjumlah 87 orang, berasal dari 4 PTS terbesar (menurut jumlah dosen) di Kota Jambi. Karakteristik responden yang akan disajikan meliputi jenis kelamin, usia, masa kerja, pangkat fungsional, dan ijazah tertinggi. Hasil tabulasi terhadap karakteristik responden disajikan pada tabel berikut. 
Tabel 2

Hasil Tabulasi Karakteristik Responden

\begin{tabular}{|c|c|c|c|c|}
\hline No & Kategori & Subkategori & Frekwensi (orang) & $\%$ \\
\hline \multirow[t]{2}{*}{1} & Jenis Kelamin & Laki-laki & 48 & 55 \\
\hline & & Perempuan & 39 & 45 \\
\hline \multirow[t]{4}{*}{2} & Usia & 25-34 tahun & 24 & 28 \\
\hline & & 35-44 tahun & 42 & 48 \\
\hline & & 45-54 tahun & 16 & 18 \\
\hline & & $\geq 55$ tahun & 5 & 6 \\
\hline \multirow[t]{6}{*}{3} & Masa Kerja & $1-5$ tahun & 25 & 28 \\
\hline & & 6-10 tahun & 30 & 34 \\
\hline & & 11-15 tahun & 9 & 10 \\
\hline & & 16-20 tahun & 9 & 10 \\
\hline & & 21-25 tahun & 5 & 8 \\
\hline & & $26-30$ tahun & 9 & 10 \\
\hline \multirow[t]{4}{*}{4} & Kepangkatan Fungsional & Asisten Ahli & 55 & 63 \\
\hline & & Lektor & 25 & 29 \\
\hline & & Lektor kepala & 7 & 8 \\
\hline & & Guru besar & - & - \\
\hline \multirow[t]{2}{*}{5} & Pendidikan Tertinggi & Magister (S2) & 84 & 97 \\
\hline & & Doktor (S3) & 3 & 3 \\
\hline
\end{tabular}

Sumber: data olahan

Tabel di atas memeprlihatkan bahwa berdasarkan jenis kelamin responden dibagi atas dua kelompok yakni kelopok laki-laki berjumlah 48 orang atau 55\% dan kelompok perempuan berjumlah 39 orang atau $45 \%$. Berdasarkan usia, responden dibagi atas empat kelompok yakni responden yang berusia 25-34 tahun sebanyak 24 orang atau 28\%, yang berusia 35-44 tahun sebanyak 42 orang atau $48 \%$, yang berusia $45-54$ orang sebanyak 16 orang atau 18\%, dan yang berusia 55 tahun ke atas sebanyak 5 orang atau $6 \%$. Berdasarkan masa kerja, responden dibagi atas dua kelompok yakni responden dengan masa kerja 1-15 tahun sebanyak 64 orang atau 70\%, dan dengan masa kerja 16-30 tahun sebanyak 23 orang atau 30\%. Data ini menunjukkan bahwa mayoritas responden berada pada usia produktif. Berdasarkan kepangkatan, responden dibagi atas empat kelompok yakni responden dengan pangkat asisten ahli sebanyak 55 orang atau $63 \%$, dengan pangkat lektor sebanyak 25 orang atau 29\%, lektor kepala sebanyak 7 orang atau $8 \%$. Ironisnya, dosen dengan pangkat guru besar tidak ada. Berdasarkan pendidikan terakhir, responden dibagi atas dua kelompok yakni kelompok dosen dengan ijazah tertinggi magister (S2) sebanyak 84 orang atau $97 \%$, dan yang berpendidikan doktor (S3) hanya 3 orang atau 3\%. Dari data ini terlihat bahwa dosen-dosen di PTS yang ada di Kota Jambi belum memenuhi kualifikasi yang ideal.

\section{Variabel Tujuan} berikut.

Untuk mengukur efektivitas variabel tujuan digunakan lima indikator seperti terlihat pada tabel

Tabel 3

Tingkat Efektivitas Tujuan

\begin{tabular}{llrcc}
\hline \multicolumn{1}{c}{ No } & \multicolumn{1}{c}{ Indikator } & Skor Aktual & Nilai & Kategori \\
\hline 1 & Kejelasan rumusan Visi Misi \& Tujuan (VMT) & 512 & 84 & Sangat Tinggi \\
2 & Kesetujuan terhadap rumusan VMT & 498 & 82 & Sangat Tinggi \\
3 & Kemudahan memahami rumusan VMT & 486 & 80 & Sangat Tinggi \\
4 & Kemudahan memahami program kerja prioritas & 455 & 75 & Tinggi \\
5 & Tingkat partisipasi dosen dalam memberi masukan terhadap & 435 & 71 & Tinggi \\
& tujuan. & & 477 & 78 Tinggi \\
\hline
\end{tabular}

Sumber: data olahan

Tujuan merupakan aspek penting dari organisasi. Setiap organisasi mesti memiliki tujuan. Tujuan organisasi biasanya tertuang dalam rumusan Visi Misi Tujuan (MVT). Tabel 3 memperlihatkan bahwa skor rata-rata yang diberikan responden terhadap variabel tujuan berada pada kategori tinggi. Ini berarti 
responden menilai bahwa pengelolaan tujuan pada PTS di Kota Jambi cukup efektif. Namun demikian masih perlu ditingkatkan. Untuk mengetahui aspek apa saja yang perlu diperbaiki dapat dilihat dari rincian skor yang diberikan responden terhadap masing-masing indikator. Skor tertinggi diberikan kepada indikator kejelasan rumusan tujuan dengan kategori sangat tinggi. Ini berarti responden sangat memahami VMT yang dirumuskan oleh PTS masing-masing. Dosen juga merasa bahwa apa yang menjadi tujuan organisasi adalah juga tujuan pribadi. Dengan kata lain terdapat kesesuaian tujuan organisasi dengan tujuan pribadi. Namun dinilai pula bahwa dosen kurang dilibatkan dalam perumusan tujuan organisasi. Hal ini disebabkan reponden memberi nilai paling rendah pada indikator ini.

Untuk mengukur efektivitas variabel struktur digunakan lima indikator seperti tgerlihat pada tabel berikut.

Tabel 4

Tingkat Efektivitas Struktur

\begin{tabular}{llrrr}
\hline No & \multicolumn{1}{c}{ Indikator } & Skor Aktual & Nilai & Kategori \\
\hline 1 & Desain struktur organisasi & 473 & 78 & Tinggi \\
2 & Peran pembagian kerja mencapai tujuan. & 473 & 78 & Tinggi \\
3 & Pembagian kerja sebagai sarana mencapai VMT & 460 & 76 & Tinggi \\
4 & Fleksibilitas pembagian kerja. & 456 & 75 & Tinggi \\
5 & Rasionalitas tuntutan terhadap cara dan perilaku kerja. & 445 & 73 & Tinggi \\
& Rata-rata & 461 & 76 & Tinggi \\
\hline
\end{tabular}

Sumber: data olahan

Struktur organisasi merupakan aspek penting. Dari struktur organisasi dapat terlihat bagai mana pola hubungan dalam satu organisasi. Tabel 4 memperlihatkan bahwa skor rata-rata yang diberikan responden terhadap variabel struktur berada pada kategori tinggi. Ini menunjukkan bahwa responden menilai pengelolaan struktur organisasi pada PTS di Kota Jambi cukup efektif namun masih perlu peningkatan. Hal ini dapat dilihat dari skor yang diberikan responden kepada indikator-indikator yang membentuk variabel ini. Skor tertinggi diberikan kepada indikator desain struktur dan peran pembagian kerja. Responden menilai bahwa mereka cukup puas dengan desain struktur dan pembagian kerja. Namun mereka tidak merasa puas dengan tuntutan kerja. Artinya, para dosen merasa tuntutan kerja kepada dosen sangat banyak. Hal ini mungkin berkaitan dengan tugas tridarma yang harus diemban setiap dosen.

\section{Variabel Kepemimpinan}

Untuk mengukur efektivitas variabel kepemimpinan digunakan lima indikator seperti tersaji dalam tabel berikut.

Tabel 5

Tingkat Efektivitas Kepemimpinan

\begin{tabular}{|c|c|c|c|c|}
\hline No & Indikator & Skor Aktual & Nilai & Kategori \\
\hline 1 & $\begin{array}{l}\text { Dukungan pimpinan terhadap usaha-usaha dosen melakukan } \\
\text { pekerjaannya. }\end{array}$ & 480 & 79 & Tinggi \\
\hline 2 & Peran usaha pimpinan mewujudkan VMT. & 479 & 79 & Tinggi \\
\hline 3 & Kejelasan arahan dan bimbingan dari pimpinan kepada dosen. & 473 & 78 & Tinggi \\
\hline 4 & $\begin{array}{l}\text { Pemahaman dosen terhadap usaha-usaha pimpinan memotivasi } \\
\text { dosen bekerja lebih baik. }\end{array}$ & 473 & 78 & Tinggi \\
\hline \multirow[t]{2}{*}{5} & $\begin{array}{l}\text { Dukungan norma-norma kepemipinan terhadap kemajuan } \\
\text { organisasi. }\end{array}$ & 462 & 76 & Tinggi \\
\hline & Rata-rata & 473 & 78 & Tinggi \\
\hline
\end{tabular}

Sumber: data olahan

Kepemimpinan merupakan jantung dari manajemen. Berjalannya fungsi-fungsi manajemen dengan baik sangat tergantung pada kepemimpinan. Bahkan Adair (2007:1) mengatakan bahwa leadership skills adalah bahan pokok dalam manajemen. Tabel 5 memperlihatkan bahwa skor rata-rata yang diberikan responden terhadap variabel kepemimpinan berada pada kategori tinggi. Ini berarti fungsi kepemimpinan menurut responden di PTS masing-masing belum maksimal walaupun sebenarnya sudah baik. Responden 
menilai bahwa para pemimpin belum bekerja secara maksimal untuk memuaskan mereka. Hal ini terbukti pula dari skor yang diberikan kepada semua indikator hanya berada pada kategori tinggi. Tidak ada satu pun indikator yang mendapat kategori sangat tinggi. Skor tertinggi diberikan kepada indikator dukungan pimpinan terhadap usaha dosen dalam melakukan pekerjaannya. Ini berarti bahwa pimpinan masih kurang dalam memberi motivasi kepada dosen. Selain itu, responden juga memberi skor paling rendah terhadap norma-norma kepemimpinan, yang berarti norma-norma yang diterapkan pimpinan masih belum maksimal dalam meningkatkan kinerja dosen. Dari fakta ini dapat diduga bahwa para dosen tidak menjadikan pimpinan sebagai role model dalam bekerja.

\section{Variabel Hubungan}

Untuk mengukur efektivitas variabel hubungan digunakan lima indikator seperti terlihat pada tabel berikut.

Tabel 6

Tingkat efektivitas Hubungan

\begin{tabular}{llrrr}
\hline No & \multicolumn{1}{c}{ Indikator } & Skor Aktual & Nilai & Kategori \\
\hline 1 & Profesionalisme dan keakraban hubungan antar dosen & 509 & 84 & Sangat Tinggi \\
2 & Keharmonisan hubungan dosen dengan pimpinan & 503 & 83 & Sangat Tinggi \\
3 & Keterbukaan dan kesediaan teman sejawat dalam & 494 & 81 & \\
& membicarakan masalah. & & & \\
4 & Keterselesaian konflik-konflik yang timbul. & 430 & 71 & Tinggi \\
5 & Keterbinaan hubungan sesama dosen & 485 & 70 & Tinggi \\
& Rata-rata & 484 & 80 & Tinggi \\
\hline
\end{tabular}

Sumber: data olahan

Setiap organisasi diharapakan setiap anggota memiliki hubungan yang harmonis sehingga suasana sinergi dan kerja sama dapat tercipta dengan baik. Tabel 3 menunjukkan bahwa nilai rata-rata yang diberikan responden kepada variabel hubungan berada pada kategori tinggi yang berarti pengelolaannya dinilai cukup efektif. Namun demikian masih perlu ditingkatkan. Responden menilai bahwa hubungan mereka dengan unsur pimpinan harmonis dan hubungan antar sesama menekankan profesionalisme dan keakraban. Namun, responden juga menilai bahwa rekan-rekan kerja mereka belum begitu terbuka dalam hal membicarakan masalah. Hal ini terlihat dari skor yang diberikan kepada aspek ini merupakan skor terendah dari semua indikator yang diukur.

\section{Variabel Imbalan}

Untuk mengukur efektivitas variabel imbalan digunakan lima indikator seperti terlihat pada tabel berikut.

Tabel 7

Tingkat Efektivitas Imbalan

\begin{tabular}{llrrr}
\hline No & \multicolumn{1}{c}{ Indikator } & Skor Aktual & Nilai & Kategori \\
\hline 1 & Peluang bagi dosen dan karyawan untuk mengembangkan & 471 & 77 & \\
& karir secara individu. & & & \\
2 & Peluang untuk diprommosikan. & 467 & 77 & Tinggi \\
3 & Prinsip kesetaraan dalam skala penggajian. & 441 & 72 & Tinggi \\
4 & Keterkaitan tugas dan pekerjaan dengan imbalan yang & 439 & 72 & Tinggi \\
& diberikan. & 428 & 70 & Tinggi \\
5 & Kesesuaian gaji dengan beban kerja. & 449 & 74 & Tinggi \\
& Rata-rata & & &
\end{tabular}

Sumber: data olahan

Imbalan merupakan faktor penting dalam memelihara dan meningkatkan motivasi kerja anggota organisasi. Imbalan yang sesuai dapat meningkatkan motivasi kerja. Sebaliknya, imbalan yang tidak sesuai dapat menimbulkan ketidakpuasan dalam bekerja. Tabel 3 memperlihatkan bahwa skor rata-rata yang diberikan responden kepada variabel imbalan berada pada kategori tinggi yang berarti dinilai cukup efektif. 
Namun demikian masih perlu ditingkatkan. Responden menilai bahwa sistem penggajian dan sistem pengembangan karir di PTS yang diteliti bagi responden belum sangat memuaskan walaupun skornya sudah tinggi. Hal ini juga diperlihatkan bahwa semua indikator yang digunakan untuk mengukur variabel ini tidak ada satu pun yang mendapat skor maksimal yakni 80 ke atas. Misalnya, peluang untuk mengembangkan karir secara individu dan peluang untuk mendapat promosi jabatan dinilai hanya pada kategori tinggi. Bahkan skor terendah yang diberikan responden adalah kepada indikator kesesuaian gaji dengan beban kerja. Dengan kata lain, responden menilai bahwa nilai gaji yang mereka terima masih lebih kecil dibandingkan dengan pengorbanan waktu, tenaga dan pikiran yang mereka sumbangkan kepada institusi. Variabel Mekanisme

Untuk mengukur efektivitas variabel mekanisme digunakan lima indikator seperti terlihat pada tabel berikut.

Tabel 8

Tingkat Efektivitas Mekanisme

\begin{tabular}{clccc}
\hline No & \multicolumn{1}{c}{ Indikator } & \multicolumn{1}{c}{ Skor Aktual } & Nilai & Kategori \\
\hline 1 & $\begin{array}{l}\text { Fungsi perencanaan dan pengawasan dalam pertumbuhan dan } \\
\text { perkembangan organisasi. }\end{array}$ & 482 & 79 & Tinggi \\
2 & $\begin{array}{l}\text { Mekanisme kerja sama antar unit kerja yang ada. } \\
\text { Gagasan pimpinan membuat dosen merasa terbantu dalam }\end{array}$ & 472 & 78 & Tinggi \\
pekerjaannya. & 454 & 75 & Tinggi \\
4 & $\begin{array}{l}\text { Ketersediaan informasi yang dibutuhkan dosen dan karyawan } \\
\text { dalam melakukan pekerjaannya. }\end{array}$ & 458 & 75 & Tinggi \\
Kesediaan antar unit untuk saling membantu pada saat & 451 & 74 & Tinggi \\
& $\begin{array}{l}\text { diperlukan. } \\
\text { Rata-rata }\end{array}$ & 463 & 76 & Tinggi \\
\hline Sumber:
\end{tabular}

Tabel 3 memperlihatkan bahwa skor rata-rata variabel mekanisme berada pada kategori tinggi. Ini menunjukkan bahwa mekanisme kerja di PTS yang diteliti masih perlu ditingkatkan. Skor tertinggi yang diberikan kepada usaha-usaha pimpinan hanya pada kategori cukup efektif atau belum maksimal. Ini berarti responden merasa bahwa pimpinan belum maksimal berusaha untuk memperlancar pekerjaan dosen. Sedangkan skor terendah yakni 74 diberikan kepada kemauan untuk saling membantu atau kerja sama. Ini menunjukkan pula bahwa fungsi kerja sama antar unit kerja sudah baik akan tetapi masih perlu ditingkatkan. Hal ini sejalan pula dengan skor yang didapat masing-masing indikator semuanya hanya berada pada kategori tinggi. Tidak ada satu pun indikator yang memperoleh skor dengan kategori sangat tinggi.

\section{Variabel Sikap terhadap perubahan}

Untuk mengukur sikap terhadap perubahan digunakan lima indikator seperti terlihat pada tabel berikut.

Tabel 9

Tingkat Efektivitas Sikap terhadap Perubahan

\begin{tabular}{|c|c|c|c|c|}
\hline No & Indikator & Skor Aktual & Nilai & Kategori \\
\hline 1 & Kemampuan PTS untuk melakukan perubahan. & 496 & 81 & Sangat Tinggi \\
\hline 2 & PTS menyukai perubahan. & 472 & 78 & Tinggi \\
\hline 3 & $\begin{array}{l}\text { Keinginan dosen secara individu untuk melakukan perubahan } \\
\text { dalam pekerjaan. }\end{array}$ & 460 & 76 & Tinggi \\
\hline 4 & $\begin{array}{l}\text { Sosialisasi kebijakan dan prosedur kerja yang baru kepada } \\
\text { dosen. }\end{array}$ & 442 & 73 & Tinggi \\
\hline \multirow[t]{2}{*}{5} & PTS ini tidak memiliki resistensi terhadap perubahan & 418 & 69 & Tinggi \\
\hline & Rata-rata & 458 & 75 & Tinggi \\
\hline
\end{tabular}

Sumber: data olahan

Lingkungan eksternal sangat dinamis. Perubahannya cepat dan sering kali tidak terduga. Perusahaan harus mampu melakukan adaptasi yang tepat untuk menyikapi perubahan tersebut. Tabel 3 memperlihatkan bahwa skor rata-rata yang diberikan responden kepada sikap terhadap perubahan berada pada kategori tinggi 
dengan skor 75. Ini berarti responden menilai bahwa PTS memiliki kemampuan melakukan perubahan namun tidak memiliki kemauan yang cukup tinggi untuk melakukan perubahan. Hal ini terlihat pula dari skor yang diberikan kepada aspek sosialisasi kebijakan berada pada kategori sangat tinggi dengan skor 81 . Skor terendah yang diberikan responden adalah kepada indikator aspek sosialisasi kebijakan. Ini berarti bahwa responden menilai PTS kurang mampu melakukan sosialisasi kebijakan yang baru. Hal ini tentu saja membuat responden kurang memahami perubahan yang ada sehingga kebijakan-kebijakan yang baru diambil kurang efektif dilaksanakan.

\section{Variabel Learning Practices}

Untuk mengukur variabel learning practices digunakan lima indikator seperti terlihat pada tabel berikut.

Tabel 10

Tingkat Efektivitas Learnig Pracitces

\begin{tabular}{llrrr}
\hline \multicolumn{1}{c}{ No } & \multicolumn{1}{c}{ Indikator } & Skor Aktual & Nilai & \multicolumn{1}{c}{ Kategori } \\
\hline 1 & Kemudahan mengakses database dan sistem informasi & 475 & 78 & Tinggi \\
2 & Ketersediaan database dan sistem informasi & 474 & 78 & Tinggi \\
3 & Kegiatan knowledge sharing. & 468 & 77 & Tinggi \\
4 & Kegiatan konversi pengetahuan & 439 & 72 & Tinggi \\
5 & Kegiatan pemerolehan dan penyimpanan pengetahuan & 429 & 70 & Tinggi \\
& (knowledge acquisition) & & & \\
& Rata-rata & 457 & 75 & Tinggi \\
\hline
\end{tabular}

Sumber: data olahan

Learning (pembelajaran) adalah perubahan pada model organisasi yang dapat mempertahankan dan memperbaiki kinerja (Alegre \& Chiva, 2008). Dengan dinamisnya lingkungan eksternal organisasi maka pembelajaran menjadi aspek yang sangat penting bagi organisasi (Akgun et al, 2007). Para pakar menilai bahwa organisasi yang melakukan pembelajaran secara efektif dapat memiliki kinerja yang superior dan daya saing jangka panjang. Tabel 10 memperlihatkan bahwa skor rata-rata yang diberikan responden kepada variabel praktek pembelajaran berada pada kategori tinggi. Ini berarti, manajemen pengetahuan di PTS di mana dosen mengajar sudah baik namun masih belum maksimal. Hal ini juga terbukti dari semua indikator yang diukur tidak ada satu pun yang mendapat skor dengan kategori sangat tinggi. Semuanya berada pada kategori tinggi. Skor tertinggi diberikan kepada kemudahan mengakses database dan sistem informasi. Keduanya berada pada kategori tinggi. Ini menunjukkan bahwa database dan akses terhadap database tersebut dinilai telah baik namun belum maksimal. Sedangkan skor terendah diberikan kepada kegiatan pemerolehan pengetahuan. Ini menunjukkan bahwa kegiatan ini dianggap paling tidak efektif walaupun sebenarnya sudah baik. Hal ini mungkin disebabkan kurangnya dukungan yang diberikan lembaga.

\section{SIMPULAN}

Hasil analisis data dapat disimpulkan sebagai berikut: (1) model diagnosis yang dikembangkan dalam penelitian ini yakni model dengan delapan variabel terbukti dapat menjelaskan efektivitas organisasi, (2) semua variabel manajemen yang diteliti dalam penelitian ini yakni tujuan, struktur, kepemimpinan, hubungan, imbalan, mekanisme, sikap terhadap perubahan, dan learning practices memiliki peran besar dalam proses manajemen pada organisasi PTS yang ada di Kota Jambi. Dengan kata lain, efektivitas dalam mengelola setiap aspek ini akan berdampak terhadap proses manajemen organisasi secara keseluruhan, (3) ditemukan bahwa walaupun peran setiap variabel yang diteliti besar terhadap proses manajemen namun skor yang diberikan responden masih dalam kategori tinggi bukan sangat tinggi. Ini berarti masih ada ruang bagi setiap variabel untuk ditingkatkan sehingga peran masing-masing menjadi maksimal, (4) dari delapan variabel yang diteliti, variabel imbalan, sikap terhadap perubahan, dan learning practices mendapat skor terendah. Ini berarti kepemimpinan belum efektif mempengaruhi motivasi, sikap, dan perilaku dosen, (5) dari empat puluh item pernyataan dalam angket yang diajukan kepada responden terdapat delapan item yang mendapat skor terendah. Dengan kata lain, setiap variabel terdapat satu item yang skornya terendah. Kedelapan item tersebut adalah: (a) tingkat partisipasi dosen dalam merumuskan tujuan PTS, (b) peran 
pembagian kerja dalam mencapai tujuan, (c) pemahaman dosen terhadap usaha-usaha pimpinan dalam mewujudkan VMT, (d) penyelesaian konflik, (e) kesesuaian gaji dengan beban kerja dan status kerja, (f) usaha kerja sama antar unit, (g) resistensi terhadap perubahan, dan (h) kegiatan pemerolehan pengetahuan atau knowledge acquisition.

Berdasarkan temuan-temuan di atas beberapa saran diberikan sebagai berikut: (1) disarankan agar setiap PTS terutama yang ada di Kota Jambi secara reguler melakukan diagnosis organisasional terutama untuk mengetahui aspek manajemen mana yang berjalan efektif dan yang tidak efektif sehingga dapat ditentukan tindakan perbaikan yang diperlukan, (2) variabel sikap mendapat skor terendah walaupun sesungguhnya skor tersebut sudah berada pada kategori tinggi. Untuk itu disarankan agar PTS-PTS yang ada di Kota Jambi memperbaiki sistem komunikasi atau meningkatkan efektivitas komunikasi dengan dosen agar dosen dapat lebih memahami apa yang menjadi aspiriasi pimpinan. (3) disarankan agar PTS di Kota Jambi meningkatkan peran kepemimpinan terutama terhadap proses hubungan baik antara anggota dengan anggota maupun antara anggota dengan pimpinan, (3) terkait dengan delapan indikator yang mendapat skor terendah disarankan sebagai berikut: (1) perlu peningkatan partisipasi dosen dalam merumuskan tujuan PTS, (2) perlu perancangan program kerja yang benar-benar sesuai dengan VMT, (3) perlu peningkatan komunikasi antara pimpinan dengan dosen terkait dengan usaha-usaha pimpinan dalam mencapai tujuan organisasi agar tercipta sinergi antara pimpinan dengan dosen, (4) perlu dirancang mekanisme penyelesaian konflik, (5) perlu perbaikan sistem imbalan yakni sistem yang benar-benar mengakomodasi kepentingan dosen, (6) perlu dirancang sedemikian rupa mekanisme kerja sama antar unit yang ada, (7) disarankan agar para pimpinan pada PTS di Kota Jambi menciptakan kondisi sedemikian rupa sehingga organisasi dapat lebih beradaptasi dengan perubahan lingkungan, (8) pimpinan PTS di Kota Jambi perlu mendesain program kerja yang mengakomodasi kegiatan pemerolehan pengetahuan, misalnya dengan (1) mendorong dosen lebih aktif menghadiri seminar, (2) merancang sistem informasi yang mudah diakses, (3) membangun database yang terupdate secara teratur.

\section{DAFTAR PUSTAKA}

Adair, J. 2007, Develop your leader skills, London dan Philadelphia: Kogan Kage.

Akgen, A. E., J. C. Byrne, G. S. Lynn, \& H. Keskin, 2007, Organizational unlearning as changes in beliefs and routines in organizations, Journal of Organizational Change Management, Vol 20(6), 794-812.

Alderfer, C.P. 2011, The practice of organizational diagnosis: theory and methods, Oxford, Oxford University Press.

Alegre \& Chiva, 2008, assessing the impact of organoizational learning capablities on product innovation performance, Technovation 28(2008), 315-326.

BPS Kota Jambi, 2018, Kota Jambi dalam Angka 2018.

Burke, W.W., \& G. H. Litwin, 1992, A causal model of organizational performance and change, Journal of Management, 18(3), 523-545.

Cooper, R., 2015, The Shared Services Organizational Model in Higher Education Enrollment Management: the Application of the Transactional Components of the Burke-Litwin Model of Organizational Performance and Change and the Moderating Effect of Employee Engagement on Individual Motivation, Human Resource Development Theses and Dissertations. Paper 9. http://hdl.handle.net/10950/310.

Cummings, T. G., \& C. G. Worley, 2008, Organization Development \& Change, Mason, USA: SouthWestern Cengage Learning.

Hamid, R., et al, 2011, The analysis of organizational diagnosis based on six box model in universities, Higher Education Studies, 1(1) 84-92.

Harrison, M.I., \& A. Shirom, 1999, Organizational Diagnosis and Assessment: Bridging Theory and Practice, California, USA: Sage Publication.

Harvey, L., 2000, New realities: the relationship between higher education and employment. Tertiary Education and Management.

Kemenristekdikti, 2017, Statistik Pendidikan Tinggi (Higher Education Statistical Year Book) 2017, Jakarta: Pusat Data dan Informasi Iptek Dikti. 
Lok, P., \& J. Crawford, 2000, The application of a diagnostic model and surveys in organizational development, Journal of Managerial Psychology, 15(2), 108-125.

Mamilo, D., 2016, Increasing Organizational Effectiveness through Organizational Diagnosis Comparison Between Public Institutions in Kosovo and Albania, International Journal of Engineering Sciences \& Researchtechnology, Vol 5(7): 587-596.

Miles, J. A., 2012, Management and organization theory, USA: Jossey-Bass.

Preziosi, R., 1980, Organizational diagnosis Questionnaire, the 1980 annual handbook for group facilitators, New Jersey, NJ: University Associates.

Saeed, B.B., \& W. Wang, 2013a, Organizational diagnosis: a survey of the literature and proposition of new diagnostic model, Int. J. Information Systems and Change management, 6(3), 222-238.

Saeed, B.B., \& W. Wang, 2013b, The Art of Organizational Diagnosis, Pathogens and Remedies, iBusiness, $5,55-58$.

Simarmata, J., 2018, Praktek manajemen kinerja dan kinerja organisasi pada Universitas Batanghari: peran budaya organisasi sebagai variabel moderator, J-MAS (Jurnal Manajemen dan Sains), Vol 3(2), 137 145.

Stegerean, R., C. Gavera, \& A. Marin, 2010, The application of diagnostic model: an empirical study, Studia Universitatis Babes-Bolyai, Negotia, LV, 5, 3-11.

Sugiyono, 2013, Metode penelitian manajemen, Bandung: Penerbit Alfabeta.

Weisbord, M. R., 1976, Organizational Diagnosis: six places to look for trouble with or without theory, Group \& Organization Studies, 1(4), 430-447.

Whitfield, G., \& R. Landeros, 2006, Supplier Diversity Effectiveness: Does Organizational Culture Really Matter?, Journal of Supply Chain Management, 42, 16-28. 